\title{
An Evaluation of the Flora Adjacent to Wine Grape Vineyards for the Presence of Alternative Host Plants of Grapevine red blotch-associated virus
}

Brian W. Bahder, and Frank G. Zalom, Department of Entomology and Nematology, University of California, One Shields Ave., Davis, CA 95616; and Mysore R. Sudarshana, USDA-ARS, Department of Plant Pathology, University of California, One Shields Ave., Davis, CA 95616

\begin{abstract}
Bahder, B. W., Zalom, F. G., and Sudarshana, M. R. 2016. An evaluation of the flora adjacent to wine grape vineyards for the presence of alternative host plants of Grapevine red blotch-associated virus. Plant Dis. 100:1571-1574.

Grapevine red blotch-associated virus $(\mathrm{GRBaV})$ is a recently discovered virus of concern to wine grape production in North America. While the vector of this virus is unknown, other elements of virus epidemiology are essential to develop guidelines for the management of the virus as well as to assist in the search for its vector. The objective of this study was to evaluate vegetation within and surrounding GRBaV-infected vineyards to identify potential virus reservoirs that may serve as sources of inoculum. In this study, 13 plant species were sampled throughout the year and were

tested for the presence of GRBaV. Of the 13 species tested, two species, Rubus armeniacus and wild grapes (Vitis californica $\times V$. vinifera), tested positive by quantitative PCR. Of these two species, only wild grapes were determined to be a true host. This study documents the first time GRBaV has been confirmed in an alternative host or in a species outside of a commercial vineyard and suggests that a mechanism exists by which GRBaV moves between plant species that is not human-mediated. The precise role that wild grapes play in the epidemiology of $\mathrm{GRBaV}$ remains unknown.
\end{abstract}

Grapevine red blotch-associated virus $(\mathrm{GRBaV})$ is a recently discovered virus associated with red blotch disease of grapevines (Al Rwahnih et al. 2013; Krenz et al. 2012; Sudarshana et al. 2015) that has been reported in various cultivars of Vitis vinifera in North America (Krenz et al. 2014). The genome of GRBaV is comprised of a singlestranded, positive-sense, circular DNA of 3,206 kilobases (kb) in size (Al Rwahnih et al. 2013; Krenz et al. 2012). Due to similarity of genome size, sequence identity, and the presence of a nonanucleotide sequence of TAATATT I AC that serves as the origin of replication (ori), GRBaV has been proposed to be placed in the family Geminiviridae. The presence of GRBaV has been confirmed from Arkansas, California, Georgia, Idaho, Maryland, New Jersey, New York, Oregon, Pennsylvania, Texas, Virginia, and Washington within the United States (Brannen et al. 2013; Krenz et al. 2014; Sudarshana et al. 2015) and from Ontario in Canada (Sudarshana et al. 2015). This widespread distribution is likely due to the dissemination of infected material prior to the discovery of the virus. While GRBaV wasn't discovered until 2012, herbarium specimens of wine grape cultivars dating to 1940 were confirmed to be infected by GRBaV (Al Rwahnih et al. 2015a) and several table grape cultivars at the National Clonal Germplasm Repository in California were also found to be infected with GRBaV (Al Rwahnih et al. 2015b).

Negative impacts of red blotch disease on grapevines have been documented by Calvi (2011) and red blotch is currently a major concern of the wine grape industry in California and elsewhere in the United States. Poojari et al. (2013) implicated the Virginia creeper leafhopper, Erythroneura ziczac, as a vector of GRBaV under greenhouse conditions. However, repeated attempts to confirm this transmission have failed thus far, leaving the vector of GRBaV under vineyard conditions unknown (B. Bahder, F. Zalom, and M. R. Sudarshana, unpublished). While establishing the vector species for $\mathrm{GRBaV}$ is essential for developing effective guidelines for managing

Corresponding author: M. R. Sudarshana;

E-mail: mysore.sudarshana@ars.usda.gov

Accepted for publication 25 March 2016.

http://dx.doi.org/10.1094/PDIS-02-16-0153-RE

This article is in the public domain and not copyrightable. It may be freely reprinted with customary crediting of the source. The American Phytopathological Society, 2016. the spread of GRBaV in vineyards, another important variable for the epidemiology of GRBaV is the host range of the virus. Establishing the presence of $\mathrm{GRBaV}$ in plant species besides $V$. vinifera is important not only for determining natural reservoirs of $\mathrm{GRBaV}$ but, also, to provide leads in the search for one or more vectors of the virus.

The primary objective of this study was to survey woody and herbaceous plant species within and surrounding GRBaV-infected vineyards in northern California to help assess the risk of natural reservoirs for infection.

\section{Materials and Methods}

Site selection. Three vineyard sites were selected to sample associated vegetation, two (NC-01 and NC-02) located in Napa County, California, and one (SC-01) located in Sacramento County, California. Both NC-01 and NC-02 were known to be infected with isolates belonging to both clades of GRBaV (CS-337-1 and CF-214-1), while SC-01 was infected with clade I (CS-337-1) isolates only. An additional location in Napa County representing undisturbed riparian habitat, about $2 \mathrm{~km}$ from the nearest vineyards, was also surveyed. Vineyard NC-01 is an experimental vineyard of the Department of Viticulture and Enology, University of California, Davis, at Oakville in the Napa Valley that was established with cultivar Cabernet Sauvignon 7 (CS-7) on rootstock 101-14. Vineyards NC-02 and SC-01 are commercial vineyards that were sampled with grower permission in Napa and Sacramento counties, respectively. Site NC-02, the second vineyard in Napa County, is comprised of Cabernet Franc. The SC-01 vineyard is an increase block consisting of rootstock 420A and self-rooted Cabernet Sauvignon. The riparian area sampled was located at the northern end of the Napa Valley at coordinates $38.6488444^{\circ}, 122.7402806^{\circ}$, and was isolated from commercial vineyards with a high abundance of wild grapes.

Sample selection and collection. For sampling plant species in and around vineyards, the most abundant woody and herbaceous plant species were sampled. Abundant is defined here as plants where 10 individuals could be sampled. A total of 10 samples were taken of each of the 13 species (Table 1). For small, herbaceous plants, the whole plant was sampled, while all woody plants were sampled by removing five leaves and a portion of the stem to extract DNA from bark scrapings. All species selected were sampled and tested in the winter, spring, summer, and fall. In the case of woody plants, all sampled plants were marked so that the same plants were sampled repeatedly. Additionally, in a small vegetable garden present at the Oakville station, tomato and pepper plants were randomly collected and tested 
for the presence of GRBaV. All field samples were stored at $4{ }^{\circ} \mathrm{C}$ until processed for nucleic acid extraction.

DNA extraction and virus detection. Total DNA was extracted from samples using the DNeasy plant mini kit (Qiagen Inc., Valencia, $\mathrm{CA}$ ). To verify the presence of $\mathrm{GRBaV}$ in plant tissue, quantitative polymerase chain reaction (qPCR) assays were conducted, using primers GVGF1 (5'-CTC GTC GCA TTT GTA AGA-3') and GVGR1 (5'-ACT GAC AAG GCC TAC TAC G-3') (Al Rwahnih et al. 2013). qPCR assays were performed in a $20-\mu l$ reaction, containing $0.15 \mu \mathrm{M}$ of each of the primers, $2 \%$ polyvinyl pyrrolidone, $0.3 \mu$ l Stratagene reference dye (1:500), $10 \mu \mathrm{l}$ of SsoFast EvaGreen supermix (BioRad Inc., Hercules, $\mathrm{CA}$ ), and $1 \mu \mathrm{l}$ of DNA template, with the remaining volume made up with nuclease-free water. Thermal cycling conditions were as follows: initial denaturation at $95^{\circ} \mathrm{C}$ for $2 \mathrm{~min}, 35$ cycles of $95^{\circ} \mathrm{C}$ for $30 \mathrm{~s}$, $62^{\circ} \mathrm{C}$ for $1 \mathrm{~min}, 72^{\circ} \mathrm{C}$ for $1.5 \mathrm{~min}$, on a Stratagene Mx3000P thermal cycler (www.genomics.agilent.com). Following amplification, high resolution melting analysis was performed to confirm the identity of the product amplified. Conditions for melting point analysis were $95^{\circ} \mathrm{C}$ for $1 \mathrm{~min}, 55^{\circ} \mathrm{C}$ for $30 \mathrm{~s}$, and $95^{\circ} \mathrm{C}$ for $30 \mathrm{~s}$ with continuous measurement of fluorescence. Samples were scored positive when the accumulated fluorescence signal crossed the threshold $(\mathrm{Ct})$ and the amplicon had a melting temperature comparable to that produced by a product amplied from a plasmid cloned with a GVGF1/GVGR1 PCR product and a GRBaV-infected grapevine source plant maintained in a greenhouse.

RNA extraction and reverse transcriptase (RT)-PCR. Plant samples that were confirmed positive by analysis of sequence data were subsequently re-extracted, using the RNeasy plant mini kit (Qiagen, Valencia, CA) to isolate total RNA. Plant samples were initially ground in guanidine buffer (Osman et al. 2012) and were treated with DNase I at $37^{\circ} \mathrm{C}$ for $25 \mathrm{~min}$, and the enzyme was inactivated at $70^{\circ} \mathrm{C}$ for $10 \mathrm{~min}$ and, then, processed according to manufacturer instructions. To establish if GRBaV was replicating in the plants that tested positive, RT-PCR was performed on the RNA extract. Reactions performed were $25 \mu \mathrm{l}$ in volume, consisting of $2 \mu \mathrm{l}$ of RNA template, $0.5 \mu \mathrm{M}$ of each primer, $5 \% 0.1 \mathrm{M}$ dithiothreitol, $8 \% 25 \mathrm{mM}$ $\mathrm{MgCl}_{2}, 20 \%$ 5× Green GoTaq Flexi buffer, 4\% $10 \mathrm{mM}$ dNTP mix, 4\% RNasin, 180 U Superscript III RT, and 0.75 U GoTaq Flexi DNA polymerase. Thermal cycling conditions were $40 \mathrm{~min}$ at $52^{\circ} \mathrm{C}$ for initial reverse transcription, followed by 35 cycles of denaturation at $95^{\circ} \mathrm{C}$ for $30 \mathrm{~s}, 30 \mathrm{~s}$ at $62^{\circ} \mathrm{C}$ for annealing, and $1.5 \mathrm{~min}$ at $72^{\circ} \mathrm{C}$ for extension, followed by a final extension period of $7 \mathrm{~min}$ at $72^{\circ} \mathrm{C}$. Amplified products were visualized by electrophoresis on a $1.5 \%$ agarose gel, using $1 \times$ Tris-acetat-EDTA buffer and staining with GelRed.

DNA sequencing and sequence analysis. To obtain sequence data from positive samples, standard PCR was re-conducted on samples testing positive by $\mathrm{qPCR}$, using the aforementioned primers. PCR was performed in $25-\mu \mathrm{l}$ reactions with $0.5 \mu \mathrm{M}$ of each primer, $200 \mu \mathrm{M}$ dNTPs, $5 \times$ Green GoTaq Flexi buffer, $25 \mathrm{mM} \mathrm{MgCl}$, and $1.5 \mathrm{U}$ GoTaq Flexi DNA polymerase with the remaining volume made up with diethylpyrocarbonate-treated water. Two microliters of DNA template were used for each reaction. Thermal cycling conditions were the same as used by Al Rwahnih et al. (2013). PCR product was visualized, as described above, on a $1.5 \%$ agarose gel. PCR products were purified using the QIAquick PCR purification kit (Qiagen, Inc, Valencia, CA) and were sequenced at the University of California, Davis, DNA Sequencing Facility on an ABI Prism 3730 genetic analyzer. Contiguous files were created using Vector NTI v. 11.5 (Life Technologies, Benicia, CA), aligned using MEGA 5.2 (Tamura et al. 2011), and were BLAST searched against the GenBank database to verify the identity of GRBaV isolates.

\section{Results}

Plant sampling and virus detection. A total of 13 different plant species were systematically surveyed throughout 2015 (Table 1). Eight of the 13 species were herbaceous plants and five species were woody plant species. Of the plant species tested for the presence of GRBaV, using qPCR, wild grapes (Vitis californica $\times V$. vinifera) and $R$. armeniacus (Himalayan blackberry) tested positive and all other species were negative for GRBaV in the initial screening (Table 1). Wild grapes that tested positive for GRBaV in winter also tested positive for $\mathrm{GRBaV}$ in other seasons, while the $R$. armeniacus plants that were positive in winter and spring were negative for GRBaV in the summer and fall (Table 1). Two of the positive wild grapes were from the isolated riparian habitat, two were from $\mathrm{NC}-01$, and one from NC-02. One of the infected wild grapevines also appeared to develop symptoms late in the year, consisting of reddened veins and mild reddening of the leaf blade (Fig. 1) that were not as pronounced as the symptoms seen in red-fruited wine grape cultivars of $V$. vinifera. Other wild grapes nearby the symptomatic vine that tested negative by PCR were asymptomatic, whereas the wild grape with symptoms was PCR positive (Fig. 1). Due to unknown parentage of this wild grape, it cannot be said if reddening was solely due to GRBaV infection, however, this reddening in PCR was absent in wild grapes that tested negative for the virus.

PCR products amplified from these samples were subsequently sequenced and were confirmed as GRBaV sharing homology with CS-337-1 (KC896624.1) and CF-214-1 (NC_022002.1) isolates in GenBank, belonging to clades 1 and 2, respectively. Sequence data obtained from the three $R$. armeniacus (KM389994, KM389996, and KM389997) testing positive for GRBaV shared 99\% nucleotide identity with isolate CF-214-1 (Fig. 2), and sequence data obtained from the five positive wild grape specimens (KU244025 to KU244029)

Table 1. Common species of plants found in and adjacent to vineyards with grapevines that tested positive for Grapevine red blotch-associated virus in northern California

\begin{tabular}{|c|c|c|c|c|c|c|}
\hline Species & Common Name & Winter $^{\mathbf{a}}$ & Springa & Summer ${ }^{\mathbf{a}}$ & Fall $^{\mathbf{a}}$ & Site \\
\hline \multicolumn{7}{|l|}{ Herbaceous plants } \\
\hline Cynodon dactlyon & Bermuda grass & $0 / 10$ & $0 / 10$ & $0 / 10$ & $0 / 10$ & NC-01, NC- 02, SC- 01 \\
\hline Eschscholzia californica & California Poppy & $0 / 10$ & $0 / 10$ & $0 / 10$ & $0 / 10$ & NC-01, NC-02, SC-01 \\
\hline Kickxia elatine & Sharppoint Fluvellin & $0 / 10$ & $0 / 10$ & $0 / 10$ & $0 / 10$ & NC-01, NC-02, SC-01 \\
\hline Malva neglecta & Common Mallow & $0 / 10$ & $0 / 10$ & $0 / 10$ & $0 / 10$ & NC-01, NC-02, SC-01 \\
\hline Plantago lanceolata & Buckhorn & $0 / 10$ & $0 / 10$ & $0 / 10$ & $0 / 10$ & NC-01, NC-02, SC-01 \\
\hline Tribulus terrestris & Puncture Vine & $0 / 10$ & $0 / 10$ & $0 / 10$ & $0 / 10$ & NC-01, NC-02 SC-01 \\
\hline \multicolumn{7}{|l|}{ Woody plants ${ }^{\mathrm{b}}$} \\
\hline Rosa sp. & Rose & $0 / 10$ & $0 / 10$ & $0 / 10$ & $0 / 10$ & NC-01, NC-02 \\
\hline Rubus armeniacus & Himalayan Blackberry & $3 / 10$ & $3 / 10$ & $0 / 10$ & $0 / 10$ & NC-01, SC-01 \\
\hline Heteromeles arbutifolia & Toyon & $0 / 10$ & $0 / 10$ & $0 / 10$ & $0 / 10$ & NC-01, NC-02 \\
\hline Ilex sp. & Holly & $0 / 10$ & $0 / 10$ & $0 / 10$ & $0 / 10$ & NC-01, NC-02 \\
\hline Quercus lobata & Valley Oak & $0 / 10$ & $0 / 10$ & $0 / 10$ & $0 / 10$ & NC-01 \\
\hline Quercus suber & Cork Tree & $0 / 10$ & $0 / 10$ & $0 / 10$ & $0 / 10$ & NC-01 \\
\hline Vitis californica $\times V$. vinifera & Wild Grape & $5 / 10$ & $5 / 10$ & $5 / 10$ & $5 / 10$ & $\mathrm{NC}-01, \mathrm{NC}-02, \mathrm{RH}^{\mathrm{c}}$ \\
\hline
\end{tabular}

${ }^{a}$ The numerator is the number of infected plants positive for GRBaV byPCR and the denominator is the total number of plants analyzed.

${ }^{\mathrm{b}}$ All woody plant species tested were the same 10 individuals tested at different times of the year.

${ }^{\mathrm{c}} \mathrm{RH}=$ Riparian habitat 
shared 99\% identity with isolate CF-214-1 (Fig. 2). Based on these data, all isolates obtained from $R$. armeniacus and wild grapes were more closely related to the genotype represented by CF-214-1 (Fig. 3). All wild grape samples amplified also generated PCR products of expected size by RT-PCR (Fig. 4), while all of the R. armeniacus samples that tested positive using PCR and qPCR subsequently tested negative by RTPCR (Fig. 4). Due to the ambiguous nature of the $R$. armeniacus results, 10 additional plants were sampled and anlayzed by PCR. One plant also tested positive for the CS-337-1 strain of GRBaV but exhibited the same pattern as the other $R$. armeniacus, in that viral RNA was not detectable by RT-PCR (data not shown). All plant samples from a vegetable garden also tested negative for the presence of GRBaV.

\section{Discussion}

This study provides the first evidence of GRBaV infection of an alternative host, a wild grape ( $V$. californica $\times V$. vinifera) outside of a vineyard. Finding GRBaV in wild grapes was not surprising, due to the presence of GRBaV in table grapes (Al Rwahnih et al. 2014) as well as the documented occurrence of other grapevine viruses occurring in other Vitis species and hybrids, both cultivated (Bahder et al. 2013; Soule et al. 2006) and wild (Klaassen et al. 2011). Due to the relatively recent discovery of GRBaV, lack of information on its biology and epidemiology, and the unknown status of the vector, the identification of the virus in naturally occurring flora outside of vineyards is important from an epidemiological perspective, because it demonstrates that there is a mechanism by which GRBaV can move between plants without human intervention. The presence of the same genotype of $\mathrm{GRBaV}$ in wild grapes immediately adjacent to vineyards and at a greater distance is indicative of a flying insect vector, because geminiviruses are not seed- or pollen-borne (Muhire et al. 2013; Sudarshana et al. 1998), with the exception of Tomato yellow leaf curl virus (Kil et al. 2016), and the observed distances are likely too great to suggest involvement of soil-borne vectors such as nematodes. Based on our data, it is unclear if GRBaV was present in wild grapes and subsequently moved into $V$. vinifera or if vineyards with infected material were the source for infection of wild grapes. However, after the first report of red blotch disease and GRBaV (Al Rwahnih et al. 2012), there has been no report of the presence of this virus in other countries, with the exception of Switzerland in grapevines imported from California in the 1980s (Reynard 2015; Reynard and Gugerli 2015). In the absence of reports of spread from the old world, it is likely that GRBaV moved from wild Vitis spp. in North America into $V$. vinifera.

The presence of GRBaV in $R$. armeniacus is intriguing, because blackberry brambles are common in vineyards in the North Coast of California. Some viruses are known to infect both grapes and blackberries (Martin et al. 2013). Grapevine Syrah virus 1 (genus: Marafivirus; family: Tymoviridae) and Tomato ringspot virus (genus: Nepovirus; family: Secoviridae) have been detected in both blackberry plants and grapevines. Recently, it was reported that E. ziczac could transmit GRBaV under greenhouse conditions (Poojari et al. 2013) and $E$. ziczac infestation of both blackberries and grapevines had been seen at site SC-01. Because of this, we examined the presence of GRBaV in $R$. armeniacus. Observations over a full year indicated that, while the same wild grapevine plants tested positive in all four seasons for

$\begin{array}{llccccccccc}1 & & 1 & 2 & 3 & 4 & 5 & 6 & 7 & 8 & 9 \\ 2 & \text { CS-337-1 } & - & & & & & & & & \\ 3 & \text { WG-128D } & 6.7 & & & & & & & & \\ 4 & \text { WG-128E } & 6.9 & 0.4 & & & & & & & \\ 5 & \text { WG-128SS } & 6.5 & 0.2 & 0.4 & 0.4 & & & & & \\ 6 & \text { WG-128Fr } & 7.4 & 0.6 & 1.0 & 0.8 & 0.8 & & & & \\ 7 & \text { WG-128De } & 6.5 & 0.2 & 0.4 & 0.4 & 0.0 & 0.8 & & & \\ 8 & \text { RA-NC1 } & 7.1 & 0.4 & 0.8 & 0.6 & 0.6 & 1.0 & 0.6 & & \\ 9 & \text { RA-NC2 } & 7.1 & 0.4 & 0.8 & 0.6 & 0.6 & 1.0 & 0.6 & 0.0 & \\ 10 & \text { RA-SC1 } & 7.1 & 0.4 & 0.8 & 0.6 & 0.6 & 1.0 & 0.6 & 0.0 & 0.0\end{array}$

Fig. 2. Pairwise comparison showing percent difference at the nucleotide level between the V2 open reading frame (ORF) of known genotypes of Grapevine red blotch-associated virus (GRBaV), CF-214-1 (clade 2) and CS-337-1 (clade 1) from California, and V2 ORF of isolates from wild grapevines and Rubus armeniacus. $\mathrm{RA}=$ Rubus aremeniacus, $\mathrm{WG}=$ wild grapevine (Vitis californica $\times$ V. vinifera), $\mathrm{CF}=$ Cabernet Franc, $\mathrm{CS}=$ Cabernet Sauvignon. Values represent percent difference.
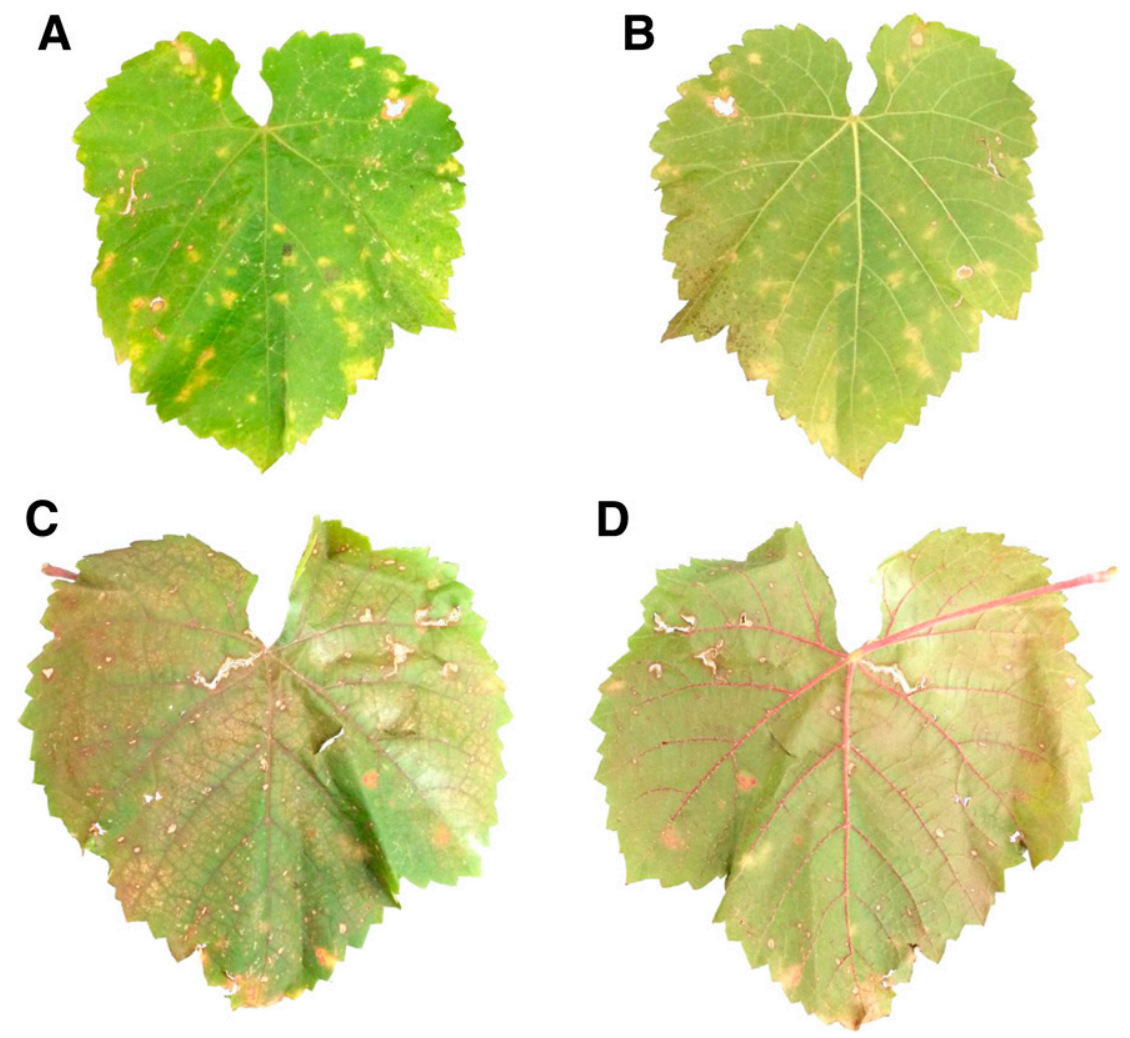

Fig. 1. A and B, Adaxial and abaxial surface of leaf blades of a specimen of a wild grapevine (Vitis californica $\times$ V. vinifera) that tested negative and $\mathbf{C}$ and $\mathbf{D}$, positive for $\mathrm{Grapevine}$ red blotch-associated virus (GRBaV) in quantitative PCR. Note pinkish veins in the leaf from GRBaV-infected wild grapevine. 
$\mathrm{GRBaV}$, the virus was detected only in winter and spring and not in the new growth in summer and fall (Table 1). To examine if the virus was replicating in blackberries, RT-PCR assays were conducted to detect transcripts of predicted virus genes. Tests for transcripts of the $\mathrm{V} 2$ gene (Fig. 4) indicated that GRBaV did not replicate in $R$. armeniacus and, thus, the virus did not become systemic in this host. The detection of GRBaV in these plants suggests a form of environmental contamination as a result of vector feeding in which the virus was introduced at the feeding site.

While GRBaV was not shown to be replicating in $R$. armeniacus, these plants may still be of epidemiological importance for GRBaV in that they likely serve as an alternative host for the vector species. The impact that $R$. armeniacus and wild grapes have on the epidemiology of GRBaV cannot be fully understood until the vector is identified. Among grapevine viruses, all known grapevine leafrollassociated viruses are largely restricted to Vitis species. In the case of GLRaV-3, a natural vector has been known for 33 years and its presence in wild grapes is not surprising. However, for GLRaV-2, a natural vector has not been found and, thus, the finding of this virus in $\mathrm{V}$. californica by Klaassen et al. (2011) suggests an obscure vector thriving in isolation. In the case of $\mathrm{GRBaV}$, once the vector is discovered, more detailed studies of its life history and movement behavior will help assess the risk that wild grapevines pose as virus reservoirs for potential infection and the significance that $R$. armeniacus plays as an alternative host for the vector, if any.

\section{Acknowledgments}

This work was supported by USDA-ARS CRIS 5306-220000-014-00D. Additional funding for this research was provided by grants from the California

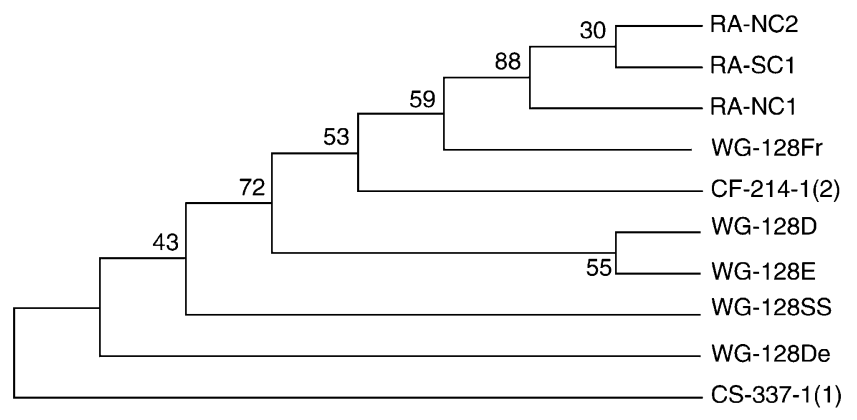

Fig. 3. Neighbor-joining tree showing relationship of Grapevine red blotch-associated virus (GRBaV) isolates from wild grapevines and Rubus armeniacus to GRBaV genotypes belonging to two clades from California, based on the nucleotide sequence of the V2 open reading frame. Values above the nodes represent boot strap values. RA $=$ Rubus aremeniacus, $W G=$ wild grapevine (Vitis californica $\times$ $V$. vinifera), $\mathrm{CF}=$ Cabernet Franc, $\mathrm{CS}=$ Cabernet Sauvignon.

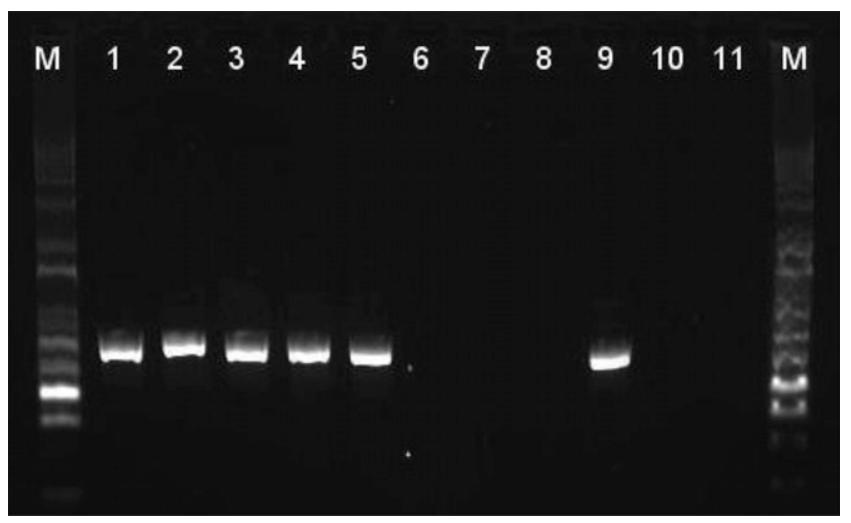

Fig. 4. Agarose gel (1.5\%) stained with GelRed visualizing reverse transcriptasePCR product for Grapevine red blotch-associated virus (GRBaV) isolates from wild grapevines (Vitis californica $\times$ V. vinifera) (lanes 1 to 5) and Rubus armeniacus (lanes 6 to 8); lane M, $1 \mathrm{~kb}+$ Ladder (Invitrogen Inc.), lane 9, GRBaV-infected Vitis vinifera. Lanes 10 and 11 , healthy grapevine and water control, respectively.
Grapevine Rootstock Improvement Commission, the California Tree Fruit and Nut Crops and Grapevine Industry Board, and the California Department of Food and Agriculture's Specialty Crops Research and Improvement Block Grant Program. The authors thank Michael Bollinger and Meredith Castillo, for assistance in sample collection and processing.

\section{Literature Cited}

Al Rwahnih, M., Ashita, D., Anderson, M. M., Rowhani, A., Uyemoto, J. K., and Sudarshana, M. R. 2013. Association of a DNA virus with grapevines affected by red blotch disease in California. Phytopathology 103:1069-1076.

Al Rwahnih, M., Dave, A., Anderson, M., Uyemoto, J. K., and Sudarshana, M. R 2012. Association of a circular DNA virus in grapevines affected by red blotch disease in California. Pages 104-105 in:Proceedings of the $17^{\text {th }}$ Congress of the International Council for the Study of Virus and Virus-like diseases of the grapevine (ICVG). Oct 7-14, Foundation Plant Services, University of California, Davis, CA

Al Rwahnih, M., Rowhani, A., Golino, D.A., Islas, C. M., Preece, J. E., and Sudarshana, M. R. 2014. Detection and genetic diversity of Grapevine red blotch-associated virus isolates in table grape accessions in the National Clonal Germplasm repository in California. Can. J. Plant Pathol. 37:130-135.

Al Rwahnih, M., Rowhani, A., and Golino, D. 2015a. First report of Grapevine red blotch-associated virus in archival grapevine material from Sonoma County, California. Plant Dis. 99:895.

Al Rwahnih, M., Rowhani, A., Golino, D., Islas, C. M., Preece, J. E., and Sudarshana, M. R. 2015b. Detection and genetic diversity of Grapevine red blotch-associated virus isolates in table grape accessions in the National Clonal Germplasm Repository in California. Can. J. Plant Pathol. 37:130-135.

Bahder, B. W., Alabi, O. J., Poojari, S., Walsh, D. B., and Naidu, R. A. 2013. A survey for grapevine viruses in Washington State 'Concord' (Vitis $\times$ labruscana L.) vineyards. Plant Health Prog. Published online. doi:10.1094/PHP-2013-0805-01-RS.

Brannen, P.M., Deom, C.M., Westmoreland, M., Collins, P., Alabi, O., and Rayapati, N. 2013. Prevalence of grapevine (Vitis vinifera) viruses in Georgia Phytopathology 103:S2.20.

Calvi, B. L. 2011. Effects of red-leaf disease on Cabernet Sauvignon at the Oakville experimental vineyard and mitigation by harvest delay and crop adjustment. M.S. thesis, University of California, Davis, CA, U.S.A.

Kil, E., Kim, S., Lee, Y., Byun, H., Park, J., Seo, H., Kim, C., Shim, J., Lee, K., Choi, H., and Lee, S. 2016. Tomato yellow leaf curl virus (TYLCV-IL): A seed-transmissible geminivirus in tomatoes. Sci. Rep. 6:19013.

Klaassen, V. A., Sim, S. T., Dangl, G. S., Osman, F., Al Rwahnih, M., Rowhani, A., and Golino, D. A. 2011. Vitis californica and Vitis californica $\times$ Vitis vinifera hybrids are hosts for Grapevine leafroll-associated virus-2 and -3 and Grapevine virus $A$ and $B$. Plant Dis. 95:657-665.

Krenz, B., Thompson, J. R., Fuchs, M., and Perry, K. L. 2012. Complete genome sequence of a new circular DNA virus from grapevine. J. Virol. 86:7715.

Krenz, B., Thompson, J. R., McLane, H. L., Fuchs, M., and Perry, K. L. 2014. Grapevine red blotch-associated virus is widespread in the United States. Phytopathology 104:1232-1240.

Martin, R. R., MacFarlane, S., Sabanadzovic, S., Quito, D., Poudel, B., and Tzanetakis, I. E. 2013. Viruses and virus diseases of Rubus. Plant Dis. 97:168-182.

Muhire, B., Matrin, D. P., Brown, J. K., Navas-Castillo, J., Moriones, E., Zerbini, F. M., Rivera-Bustamante, R., Malathi, V. G., Briddon, R. W., and Varsani, A. 2013. A genome-wide pairwise-identity-based proposal for the classification of viruses in the genus Mastrevirus (family Geminivirdae). Arch. Virol. 158:1411-1424.

Osman, F., Olineka, T., Hodzic, E., Golino, D., and Rowhani, A. 2012. Comparative procedures for sample processing and quantitative PCR detection of grapevine viruses. J. Virol. Methods 179:303-310.

Poojari, S., Alabi, O. J., Fofanov, V. Y., and Naidu, R. A. 2013. A leafhoppertransmissible DNA virus with novel evolutionary lineage in the family Geminiviridae implicated in grapevine redleaf disease by next generation sequencing. PLoS One 8:e64194.

Reynard, J. S. 2015. Survey of emerging viruses in Switzerland. Pages 223-224 in: Proceedings of the $18^{\text {th }}$ Congress of the International Council for the Study of Virus and Virus-like diseases of the grapevine (ICVG). Sept 7-11. Ankara University, Ankara, Turkey.

Reynard, J. S., and Gugerli, P. 2015. Effects of Grapevine red blotch-associated virus on vine physiology and fruit composition of field grown grapevine cv. Gamay. Pages 234-235 in: Proceedings of the $18^{\text {th }}$ Congress of the International Council for the Study of Virus and Virus-like diseases of the grapevine (ICVG). Sept 7-11. Ankara University, Ankara, Turkey.

Soule, M. J., Eastwell, K. C., and Naidu, R. A. 2006. First report of Grapevine leafroll associated virus-3 in American Vitis spp. grapevines in Washington state. Plant Dis. 90:1461.

Sudarshana, M. R., Perry, K. L., and Fuchs, M. F. 2015. Grapevine red blotch-associated virus, an emerging threat to the grapevine industry. Phytopathology 105:1026-1032

Sudarshana, M. R., Wang, H. L., Lucas, W. J., and Gilbertson, R. L. 1998. Dynamics of bean dwarf mosaic geminivirus cell-to-cell and long-distance movement in Phaseolus vulgaris revealed, using the green fluorescent protein. Mol. Plant-Microbe Interact. 11:277-291.

Tamura, K., Peterson, D., Peterson, N., Stecher, G., Nei, M., and Kumar, S. 2011 MEGA5: Molecular evolutionary genetics analysis using maximum likelihood evolutionary distance, and maximum parsimony methods. Mol. Biol. Evol. 28: 2731-2739. 